\section{RSP}

http://www.rsp.fsp.usp.br/
Revista de Saúde Pública

\title{
Access to childbirth care by adolescents and young people in the Northeastern region of Brazil
}

\author{
Érida Zoé Lustosa Furtado', Keila Rejane Oliveira Gomes", Silvana Granado Nogueira da Gama"' \\ I Hospital Universitário da Universidade Federal do Piauí. Teresina, Pl, Brasil \\ " Programa de Pós-Graduação em Ciências e Saúde. Centro de Ciências da Saúde. Universidade Federal do \\ Piauí. Teresina, PI, Brasil \\ III Programa de Pós-Graduação em Epidemiologia em Saúde Pública. Escola Nacional de Saúde Pública. \\ Fundação Oswaldo Cruz. Rio de Janeiro, RJ, Brasil
}

Correspondence:

Érida Zoé Lustosa Furtado

Rua Jornalista Dondon, 2933 apto.

2004 Horto Florestal

64052-850 Teresina, PI, Brasil

E-mail: eridazoe@hotmail.com

Received: 19 Feb 2014

Approved: 10 Jun 2015

How to cite: Furtado EZL, Gomes KRO, Gama SGN. Access to childbirth care by adolescents and young people in the Northeastern region of Brazil. Rev Saude

Publica. 2016;50:23.

Copyright: This is an open-access article distributed under the terms of the Creative Commons Attribution License, which permits unrestricted use, distribution, and reproduction in any medium, provided that the original author and source are credited.

\section{ABSTRACT}

OBJECTIVE: To identify the factors that interfere with the access of adolescents and young people to childbirth care for in the Northeast region of Brazil.

METHODS: Cross-sectional study with 3,014 adolescents and young people admitted to the selected maternity wards to give birth in the Northeast region of Brazil. The sample design was probabilistic, in two stages: the first corresponded to the health establishments and the second to women who had recently given birth and their babies. The data was collected by means of interviews and consulting the hospital records, from pre-tested electronic form. Descriptive statistics were used for the univariate analysis, Pearson's Chi-square test for the bivariate analysis and multiple logistic regressions for the multivariate analysis. Sociodemographic variables, obstetrical history, and birth care were analyzed.

RESULTS: Half of the adolescents and young people interviewed had not been given guidance on the location that they should go to when in labor, and among those who had, $23.5 \%$ did not give birth in the indicated health service. Furthermore, one third (33.3\%) had to travel in search of assisted birth, and the majority (66.7\%) of the postpartum women came to maternity by their own means. In the bivariate analysis, the variables marital status, paid work, health insurance, number of previous pregnancies, parity, city location, and type of health establishment showed a significant association $(\mathrm{p}<0.20)$ with inadequate access to childbirth care. The multivariate analysis showed that married adolescents and young people $(\mathrm{p}<0.015)$, with no health insurance $(\mathrm{p}<0.002)$ and from the countryside $(\mathrm{p}<0.001)$ were more likely to have inadequate access to childbirth care.

CONCLUSIONS: Adolescents and young women, married, without health insurance, and from the countryside are more likely to have inadequate access to birth care. The articulation between outpatient care and birth care can improve this access and, consequently, minimize the maternal and fetal risks that arise from a lack of systematic hospitalization planning.

DESCRIPTORS: Pregnancy in Adolescence. Midwifery. Birthing Centers. Health Services Accessibility. Health Inequalities. 


\section{INTRODUCTION}

To meet their requirements in the area of health, users must overcome one essential step: access to these services ${ }^{18}$. Studies on access to health services can make a contribution regarding the organization of care, which enable levels of coverage and identification of priority populations to be established in health care. In addition, these studies are useful in terms of establishing public policies that ensure universal and equal access to health care and in the reorganization of their systems, all of which can minimize inequalities in health ${ }^{10}$.

During the 1990s, Brazil saw an expansion in the primary health care system, marked by the implementation of the Community Health Agents Program and the Family Health Program. Following the year of 2000, the income gap between the rich and poor began to decrease, which can mostly be attributed to income transfer programs and the increase in wages for unskilled labor. In addition, large investments were made in basic education during the 1990s, which resulted in an improvement in the education levels of Brazilian mothers that had never been previously reached. These changes had a role in improving the level of care provided during labor and childbirth in Brazil ${ }^{22}$.

Despite the level of prenatal and birth care being high, these care stages remain poorly integrated. It is difficult for pregnant women to be hospitalized during their child's delivery, a fact that is still relevant to maternal and child morbidity and mortality and reflects a lack of organization of the health system as an effective referral, counter-referral, transportation and communication system. This problem is a common occurrence in public institutions, where it is difficult to establish a link between pregnant women and the health system. The result of this separation is that the history of the pregnancy is not known and that there is insufficient planning regarding hospitalizations during childbirth ${ }^{4,13,15}$.

In Latin America and the Caribbean, the largest proportion of childbirths that were given medical and hospital care were seen in the Dominican Republic, Brazil and Colombia ${ }^{19}$. Considering that $95.0 \%$ of births in Brazil take place in hospitals, discussing access to maternity wards is a pertinent subject. The greater the distance that the pregnant woman has to travel, the harder it is for her to access health services and, during this potentially lengthy trip, the ongoing labor becomes complicated and risky. This situation can reduce the chances of the pregnant women receiving suitable care, since many health services are not equipped to deal with the more complex cases - which is especially true in the Northeast region of Brazil, where the number of neonatal intensive care units per 1,000 live births is the smallest in the country ${ }^{2,4}$.

Thus, determining the risk of a pregnancy becomes useless if the woman does not have access to the maternity ward in a timely manner. Some of the reasons for this delay include the long distances to be travelled and the lack of an effective transport system, as well as poor communication and referral systems ${ }^{15}$.

The objective of our study is to identify factors that interfere with access to childbirth care by adolescents and young women in Brazil's Northeast region.

\section{METHODS}

This study is cross-sectional in nature, complementing a broader research project performed by the Oswaldo Cruz Foundation (Fiocruz), titled "Born in Brazil: national survey on childbirth". The methodology used in this study is detailed in Leal et al. ${ }^{14}$ (2012).

The subjects involved in our research were 12 to 24 year-old adolescent and young women who had recently given birth. These women had been admitted to the selected maternity wards in the Northeast region of Brazil to give birth. This age group was chosen because pregnancy in these groups is associated with greater social vulnerability, which is especially 
true during adolescence. In addition, becoming pregnant during adolescence may result in negative consequences for the mother's health ${ }^{20}$ and adverse neonatal outcomes such as low birth weight and prematurity, which are considered significant causes of infant and neonatal death ${ }^{23}$. Furthermore, this section of the population experiences difficulties in terms of access to care, such as geographical and economic barriers, in addition to services being offered at times that are incompatible with the users' needs and an insufficient number of professionals who are ready to care for them ${ }^{6}$.

The study sample was stratified by major geographical regions in Brazil (North, Northeast, Southeast, South, and Midwest), by municipal location (state capital and countryside), and by type of establishment (public, private and mixed), considering that there are variations regarding cesarean sections. The health care establishments were classified according to information contained in the Brazilian National Register of Health Establishments, with the private establishments that have a funding agreement with the Brazilian Unified Health System (SUS) being categorized as mixed.

Thus, 30 sampling strata were created including all the Brazilian states. The selected health establishments in each of the five macro-regions were made up of five substrates: state capital, countryside, public, private, and both public and private (mixed). A two-stage probability sampling method was used in each stratum to define, firstly, the sample corresponding to the health establishments and, subsequently, the new mothers and their conceptions (living newborn or stillborn).

The sample size in each stratum was calculated based on the cesarean section rate in Brazil from 2007, which obtained a minimum sample of 341 women per stratum. As the sampling was done by conglomerates, a design effect of 1.3 was used, totaling a sample of approximately 450 new mothers per stratum. Regarding the health establishments, a total of 266 hospitals were sampled for the study base, with the number of randomly selected establishments ranging from five to 39, depending on the size of the substrate. Within each substratum, the establishments had a probability of being selected that was proportionate to their size. Therefore, each hospital included in the study had the same sample size, which was 90 pairs of new mothers and their babies ${ }^{14}$.

To ensure that the estimates obtained were similar to the number of births from the 2011 population sample, a calibration procedure was performed. This procedure involved weighting the data being calculated by inversing of the inclusion probability of each new mother in the sample. Thus, the results obtained are estimates of the population of new mothers studied $(337,451)$, which are based on the sample of 3,014 adolescents and young people who were interviewed.

The data were collected by previously trained interviewers through the central coordination of the study base between February 2011 and October 2012.

Only health institutions that registered 500 births/year or more were eligible for the study sample. New mothers who conceived infants (alive or dead) aged $\geq 22$ gestational weeks or with a birth weight of $\geq 500 \mathrm{~g}$ at these establishments participated in this study. Women who delivered their infants at these health facilities but who had severe mental illness, were homeless, foreigners who could not understand or speak Portuguese, individuals with hearing or speech impairment, and those who were prevented from involvement by court order were excluded from the study.

The data were collected from the study base using three basic electronic forms: the first was applied to women who had recently given birth (at least six hours after childbirth); the second was filled based on the clinical chart data, and the third was applied over the phone to the mother between 45 and 60 days after childbirth. For this study, issues of interest were selected and included in the first and second forms. 
The selected variables were related to demographic data (age, marital status, education, work status, economic class, and health insurance), obstetric history (number of previous pregnancies and parity) and variables related to childbirth care (information regarding the delivery location, child delivery at the indicated location, care sought elsewhere, method of travel to the maternity ward, and presence of an accompanying person).

The data were analyzed using the Statistical Package for the Social Science (SPSS) software, version 17.0. Descriptive statistics were used for the univariate analysis. For the bivariate analysis, Pearson's Chi-square test $\left(\chi^{2}\right)$ or Fisher's exact test, when appropriate, were used. Multiple logistic regression was used to explain the joint effect of the independent variables on the dependent variable - access to childbirth care. The inclusion criterion for variables in the logistic model was an association with socioeconomic characteristics and reproductive aspects with a $p$-value of $<0.20$ in the bivariate analysis ${ }^{11}$. An association with a $\mathrm{p}$-value of $<0.05$ in the model was considered.

The term "access" was used to describe the act of including childbirth care within health services in a timely manner, since the difficulty in gaining access harms reaching suitable care and may cause a delay in such, which contributes to additional health problems for the woman and the fetus. Thus, it was considered that the young and adolescent new mothers who traveled in search of childbirth care had inadequate access, while the others did obtain adequate access to health services.

A variance inflation factor of above four was adopted as a cut-off point for diagnosing multicollinearity ${ }^{a}$. However, the test did not detect multicollinearity among the independent variables under study.

Performing this study as a complementary design of the base study was authorized by the central coordination, which was done through design analysis and disclaimer information to use part of the database. The study was submitted and approved by the Fiocruz Ethics and Research Committee (Opinion 92/10) and health institutions from which the data was collected, all in accordance with the ethical-legal guidelines for research involving human beings, as described in Resolution 196/96 of the Brazilian National Health Council.

\section{RESULTS}

The participants involved in this study were aged between 12 and 24 years, with an average age of around 20 years ( $\mathrm{SD}=2.84$ ), most of whom occupied the 20 to 24 years age group (56.2\%). The majority of adolescents and young women mentioned being married (77.6\%), having an education level of up to middle school (54.6\%) and belonging to economic classes $\mathrm{D}$ and $\mathrm{E}(50.7 \%)$. Less than $1 / 5$ of those interviewed had a paying job (16.7\%) and almost none had health insurance (90.9\%). A significant portion of the adolescents and young women were from the countryside (79.7\%) and more than half received care through SUS (53.1\%). Regarding reproductive aspects, $58.1 \%$ were first-time mothers and, among those who had become pregnant before, $22.8 \%$ had underwent only one other birth (Table 1).

Inadequate access to childbirth care was a reality for $32.2 \%$ of the new mothers (adolescents and young women). As for the characterization of the population about access to childbirth care, $50.0 \%$ of the interviewed women were not informed as per where they should go to give birth. Among those who were informed, $23.5 \%$ did not give birth at the health service that was indicated and one third (33.3\%) had to look for alternative childbirth care. Two in three of the new mothers (66.7\%) traveled to the maternity ward by their own or other means, and 76.7\% reported being accompanied by another individual during hospitalization (Table 2).

${ }^{a}$ Garson GD. Statnotes: topics in multivariate analysis. Reliegh: NC State University; [s.d.] [cited 11 Jul 2013]. Available from: http://faculty.chass.ncsu.edu/ garson/pa765/statnote.htm
The data in Table 3 shows that inadequate access to childbirth care had a significant association $(p<0.05)$ with being married, having no health insurance, and being from the countryside. 
Table 1. Sociodemographic characterization and reproductive history of the new adolescent and young mothers in the Northeast region of Brazil, 2012.

\begin{tabular}{|c|c|c|}
\hline Variable & $\mathbf{n}$ & $\%$ \\
\hline \multicolumn{3}{|l|}{ Sociodemographic characterization } \\
\hline \multicolumn{3}{|l|}{ Age group (years) } \\
\hline $12-19$ & 1,320 & 43.8 \\
\hline $20-24$ & 1,694 & 56.2 \\
\hline \multicolumn{3}{|l|}{ Marital status } \\
\hline No martial ties & 674 & 22.4 \\
\hline With martial ties & 2,337 & 77.6 \\
\hline \multicolumn{3}{|l|}{ Education } \\
\hline Complete elementary school or less & 1,642 & 54.6 \\
\hline Incomplete high school and over & 1,363 & 45.4 \\
\hline \multicolumn{3}{|l|}{ Working } \\
\hline No & 2,511 & 83.3 \\
\hline Yes & 502 & 16.7 \\
\hline \multicolumn{3}{|l|}{ Economic class } \\
\hline $\mathrm{A}+\mathrm{B}+\mathrm{C}$ & 1,474 & 49.3 \\
\hline $\mathrm{D}+\mathrm{E}$ & 1,516 & 50.7 \\
\hline \multicolumn{3}{|l|}{ Health insurance } \\
\hline No & 2,735 & 90.9 \\
\hline Yes & 274 & 9.1 \\
\hline \multicolumn{3}{|l|}{ Origin } \\
\hline Countryside & 2,401 & 79.7 \\
\hline Capital city & 613 & 20.3 \\
\hline \multicolumn{3}{|l|}{ Type of establishment } \\
\hline Brazilian Unified Health System & 1,599 & 53.1 \\
\hline Mixed & 1,276 & 42.3 \\
\hline Private & 139 & 4.6 \\
\hline \multicolumn{3}{|l|}{ Reproductive history } \\
\hline \multicolumn{3}{|l|}{ Number of previous pregnancies } \\
\hline First pregnancy & 1,749 & 58.1 \\
\hline One & 748 & 24.8 \\
\hline Two or more & 515 & 17.1 \\
\hline \multicolumn{3}{|l|}{ Parity } \\
\hline Primipara & 1,956 & 64.9 \\
\hline One previous childbirth & 687 & 22.8 \\
\hline Two or more previous childbirths & 371 & 12.3 \\
\hline
\end{tabular}

Table 2. Distribution of new mothers according to variables related to access and delivery location. Northeastern region of Brazil, 2012.

\begin{tabular}{lcc}
\hline Variable & $\%$ & $\mathrm{Cl} 95 \%$ \\
\hline Inadequate access to childbirth care & 32.2 & \\
$\begin{array}{l}\text { Delivered at the indicated location* } \\
\text { Yes }\end{array}$ & 76.5 & $71.3-81.0$ \\
$\quad$ No & 23.5 & $19.0-28.7$ \\
Given information regarding the delivery location & & \\
$\quad$ Yes & 50.0 & $46.6-53.9$ \\
$\quad$ No & 50.0 & $46.6-53.9$ \\
Sought care elsewhere & & \\
$\quad$ Yes & 33.3 & $28.1-38.9$ \\
$\quad$ No & 66.7 & $61.1-71.9$ \\
Method of traveling to maternity ward & & \\
Own or with others & 67.6 & $63.0-71.8$ \\
Ambulance or official vehicles & 32.4 & $28.2-37.0$ \\
Accompanying person & & \\
$\quad$ Yes & 76.7 & $70.0-82.3$ \\
$\quad$ No & 23.3 & $17.7-30.0$ \\
\hline
\end{tabular}

* Question only posed to the women who claimed to have received information regarding the delivery location. 
Table 3. Bivariate analysis and multiple logistic regression model for inadequate access to childbirth care by adolescent and young new mothers. Northeastern region of Brazil, 2012.

\begin{tabular}{|c|c|c|c|c|c|}
\hline \multirow{3}{*}{ Variable } & \multicolumn{5}{|c|}{ Inadequate access to childbirth care } \\
\hline & \multicolumn{3}{|c|}{ Bivariate } & \multicolumn{2}{|c|}{ Multivariate } \\
\hline & Yes (\%) & No $(\%)$ & $p^{a}$ & ORa $(95 \% \mathrm{Cl})$ & $\mathbf{p}^{\mathbf{b}}$ \\
\hline \multicolumn{6}{|l|}{ Age group (years) } \\
\hline $12-19$ & 34.6 & 65.4 & \multirow{2}{*}{0.362} & - & \multirow{2}{*}{ - } \\
\hline $20-24$ & 32.3 & 67.7 & & & \\
\hline \multicolumn{6}{|l|}{ Marital status } \\
\hline Single & 28.5 & 71.5 & \multirow{2}{*}{0.016} & 1 & \multirow{2}{*}{0.015} \\
\hline Married & 34.7 & 65.3 & & $1.34(1.05-1.71)$ & \\
\hline \multicolumn{6}{|l|}{ Reported skin color } \\
\hline White & 33.2 & 66.8 & \multirow{2}{*}{0.975} & - & \multirow{2}{*}{ - } \\
\hline Non-White & 33.3 & 66.7 & & - & \\
\hline \multicolumn{6}{|l|}{ Literate } \\
\hline No & 36.1 & 63.9 & \multirow{2}{*}{0.673} & - & \multirow{2}{*}{ - } \\
\hline Yes & 33.3 & 66.7 & & - & \\
\hline \multicolumn{6}{|l|}{ Education } \\
\hline Complete elementary school or less & 33.2 & 66.8 & \multirow{2}{*}{0.952} & - & \multirow{2}{*}{ - } \\
\hline Incomplete high school and over & 33.4 & 66.6 & & - & \\
\hline \multicolumn{6}{|l|}{ Working } \\
\hline No & 34.1 & 65.9 & \multirow{2}{*}{0.062} & & \\
\hline Yes & 29.2 & 70.8 & & & \\
\hline \multicolumn{6}{|l|}{ Economic class } \\
\hline $\mathrm{A}+\mathrm{B}+\mathrm{C}$ & 31.8 & 68.2 & 0241 & - & \\
\hline $\mathrm{D}+\mathrm{E}$ & 35.1 & 64.9 & 0.241 & - & - \\
\hline Health insurance & & & & & \\
\hline No & 34.7 & 65.3 & -0 & 1 & $000 ?$ \\
\hline Yes & 20 & 80 & $<0.00$ & $0.45(0.28-0.73)$ & 0.002 \\
\hline Origin & & & & & \\
\hline Capital city & 31.5 & 68.5 & & 1 & \\
\hline Countryside & 40.5 & 59.6 & $<0.001$ & $1.26(1.42-3.58)$ & $<0.001$ \\
\hline Type of establishment & & & & & \\
\hline SUS & 26.9 & 73.1 & & & \\
\hline Mixed & 44.1 & 55.9 & $<0.001$ & - & - \\
\hline Private & 9.4 & 90.6 & & - & \\
\hline No. previous pregnancies & & & & & \\
\hline Up to one & 34.4 & 65.6 & 0.060 & & \\
\hline Two or more & 28 & 72 & 0.000 & & \\
\hline Parity & & & & & \\
\hline Up to one & 34 & 66 & 0179 & - & - \\
\hline Two or more & 28.2 & 71.8 & $0.1 / 9$ & - & - \\
\hline Previous abortion & & & & & \\
\hline No & 30.1 & 69.9 & 0542 & - & - \\
\hline Yes & 33.2 & 66.8 & 0.042 & - & 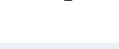 \\
\hline Number of previous miscarriages & & & & & \\
\hline Up to one & 30.7 & 69.3 & 0519 & - & \\
\hline Two or more & 37.7 & 62.3 & 0.519 & - & - \\
\hline Planned pregnancy & & & & & \\
\hline No & 31.2 & 68.8 & ( 280 & - & \\
\hline Yes & 33.2 & 66.8 & 0.200 & - & - \\
\hline
\end{tabular}

${ }^{a}$ Chi-square or Fisher Test, $\mathrm{p}<0.200$ significance level.

${ }^{\mathrm{b}}$ Multiple Logistic Regression, $\mathrm{p}<0.05$ significance level.

Statistically significant values are in bold font. 


\section{DISCUSSION}

Adolescents and young women who were married, who did not have health insurance, or who were from the countryside had a higher chance of experiencing inadequate access to childbirth health care. In addition, half of the new mothers were not informed about the place to give birth, and among those who were, a significant portion were not able to get care at the indicated location. Pregnancy during adolescence is more common among lower-income groups with a low level of education and family income. This group becomes sexually active, gets pregnant, and gets married earlier in life when compared to other groups of women ${ }^{12,16}$. The Northeastern region of Brazil is considered one of the poorest areas of the Country, and its inhabitants find it most difficult to access health services ${ }^{16}$, which may explain the high incidence of adolescent pregnancy, as well as the precarious socioeconomic conditions of the participants from this research.

Demand for health services results from the population's combined social, cultural, and individual situations. The determinants for using these types of services include the sociodemographic characteristics of the individuals in question ${ }^{3}$. In Brazil, groups that have the greatest health needs are precisely those that have the most difficulty accessing and using health care services ${ }^{21}$.

This study found that married adolescents and young women who had recently given birth have a higher propensity for inadequate access to childbirth care. What may have contributed to this association is that certain social conditions, such as marriage and family commitment, coupled with a low socioeconomic level and lack of paid work, make it impossible for these women to pay someone to take care of their house and existing children, which can have a negative influence on how these women look after themselves.

We observed that not having health insurance has a significant association with inadequate access to childbirth care. Having health insurance has been demonstrated to be directly related to family income ${ }^{5}$. Public health services have also been shown to be mostly used by individuals with poor socioeconomic conditions, with SUS caring for more than $80.0 \%$ of adolescent pregnant women ${ }^{7,16}$.

One study that investigated access to health services by adolescents and adults in the city of Pelotas, Rio Grande do Sul, Brazil, noted that the demand for health care services seemed low, in particular from the section of the population with no health insurance, and that concentration of this demand came from poorer groups. This evidence suggests that the inequality in access to health services in Brazil is a result of the institutional arrangement that allows more access to the system by individuals who are able to pay for it. Similarly, empirical international evidence supports the idea of there being inequalities in societies that opt for mixed financing in health systems ${ }^{17}$.

In the Brazilian countryside, adolescents and young women are more likely to have inadequate access to childbirth care. In Brazil, health services are concentrated in urban areas, capitals, and central areas, with the rural, poorer, and peripheral areas being neglected as a result. Thus, the smaller the size of the population, the greater distance the parturient woman has to travel, which is probably due to the concentration of establishments with obstetric beds being in large cities. In addition, socioeconomic and cultural factors play a role in the great inequality in the supply and the increased difficulty of accessing health services ${ }^{2}$.

Therefore, the results from this study reinforce the assumption that the possibility of using a certain type of care is associated with, among other factors, the income of the individual and coverage by health insurance. This scenario reproduces the social inequalities within the system to the extent that the chances of choosing the services are limited by these factors ${ }^{3}$.

However, despite there having been various policies aimed at maternal and child health implemented in recent decades, representing important advances in Brazil's health indicators, there are still inequalities to be overcome. One example of these inequalities is the inadequate 
access to childbirth care being significantly associated with not using the health insurance observed in this study. Thus, it is a matter of urgency that all citizens are guaranteed access to good quality resolutive public health actions, especially when considering the most economically and socially vulnerable strata of women from the poorest regions of Brazil, most of who are SUS users.

Only half of the women in the study were given guidance regarding which hospital unit to head to when going into labor. This percentage was lower than that observed in the 2009 national survey, which showed that around $60.0 \%$ of mothers reported having been given this advice, while almost $90.0 \%$ of births took place at the first maternity unit that the mothers found during labor ${ }^{16}$. Our result reinforces what was observed during a research project performed in the municipality of Rio de Janeiro ${ }^{8}$ and denounces the fragility or even absence of a regionalized care system focused on childbirth. The result also highlights the inadequate supply of beds in light of demand, and may increase maternal and neonatal risks due to possible obstetric complications that contribute to timely care, which could prevent fatal complications, not being available.

The Northeast region of Brazil has the lowest percentage of all regions regarding to this guidance, despite it being the responsibility of the health professionals who care for these women to provide it ${ }^{16}$. Nevertheless, developing a system that is focused on the child-bearing process and childbirth itself to help organize this flow depends on what the competent authorities can organize. However, doing so only makes sense in cities or micro-regions in which there is more than one maternity unit, because the lack of such organization transfers the burden of searching for and finding maternity hospitals with available beds, when going into labor, for women ${ }^{16}$.

Even among those who received guidance, there are a significant number of adolescents and young women who are not able to reach the indicated health service, with about one third of these individuals going to another service to seek care. In this way, continuous care during the prenatal and childbirth periods, despite their importance and legal support, through Law 11,634, of December 27, 2007 ${ }^{\mathrm{b}}$, has not been achieved. Even when the pregnant women look for the hospitals that they have been referred to, the binomial prenatal-postpartum is not always covered by these services, since the basic units perform formal referrals to other hospitals, which do not always happen ${ }^{1}$.

The situation is even more critical when patients have to travel around looking for care at other establishments by their own means ${ }^{4,15}$. In this study, less than one third of the interviewees were transported to the care unit by ambulance, with the other two thirds having to find a suitable place to give birth on their own, which reinforces the lack of hierarchy in the network, despite there being an adequate communication and transport system in the Northeast region of Brazil. In addition to the weakness of health care during pregnancy being shown by the little expectation of hospitalization, there can still be harm for parturient women, who are often in labor or in risky situations, while the long distances traveled to find a health unit to give birth constitute potential risk for the maternal-fetal outcome $e^{4,15}$.

${ }^{\mathrm{b}}$ Brasil. Lei $\mathrm{n}^{\mathrm{o}} 11.634$, de 27 de dezembro de 2007. Dispõe sobre o direito da gestante ao conhecimento a vinculação à maternidade onde receberá assistência no âmbito do Sistema Único de Saúde. Diario Oficial Uniao. 28 dez 2007

${ }^{c}$ Brasil. Lei no 11.108, de 7 de abril de 2005. Altera a Lei no 8.080 , de 19 de setembro de 1990, para garantir às parturientes o direito à presença de acompanhante durante o trabalho de parto, parto e pós parto imediato, no âmbito do Sistema Único de Saúde - SUS. Diario Oficial Uniao. 8 abr 2005

Another relevant point to consider in childbirth care for adolescents and young women is emotional support to women during labor and birth itself, which is increasingly emphasized when breaking the solitude imposed on her by traditionally established institutional routines, by providing more favorable obstetric and neonatal results ${ }^{9}$. These were the reasons that led to the enactment of law 11,108, April 2005', which ensures that women are not alone during childbirth or postpartum in SUS maternity wards.

The rate at which women have had company has increased substantially when compared to what was observed in 2009, when the Northeast region obtained a lower frequency of this variable in relation to percentages from the rest of Brazil. However, the frequency of this variable is still less than desirable. It is believed that the infrastructural limitation of most Brazilian maternity wards using an accompanying person chosen by the women, without 
compromising the privacy of others, has hampered the implementation of this measure. There is also resistance from the institutions, which is based on a fear that the presence of an accompanying person will disrupt the established work routine ${ }^{16}$.

Therefore, the health system is constantly encouraged not to consider childbirth care as an isolated procedure that has no link to prenatal care, and to create articulation strategies at the different levels of care complexity. The difficulty of accessing health services leads to preventable deaths that occur in the North and Northeast regions of Brazil, these are both maternal as well as fetal and neonatal, which is in spite of the rate of births occurring in health units in Brazil having increased from $91.0 \%$ to $98.0 \%{ }^{16}$.

Thereby, the inseparable nature of prenatal and childbirth care is vitally important and must be taken into account by health managers, given the high vulnerability of this population group. In this sense, especially in the poorest regions of Brazil, the implementation of the Brazilian Rede Cegonha [Stork Network] government program is expected to expand and qualify the care given to pregnant women and new mothers, thereby providing dignity, humanity, and security during the child-bearing period and birth itself ${ }^{\mathrm{d}}$.

Based on the aforementioned, it can be inferred that important reforms must be made regarding childbirth care in the Northeast region of Brazil. Thus, all pregnant women, when going through prenatal care, should be given information about the maternity unit they should go to when in labor. Whenever there are no free beds in the indicated maternity ward, the pregnant women should be forwarded to another central line of maternity beds and must never go looking for another unit by themselves, as is still observed at a significant percentage in the new mothers from our study.

Therefore, this study's hypothesis was proved correct, there is a challenge for the health system to improve articulation between outpatient care and childbirth care, which is especially true in public institutions, where it is difficult to establish a link between pregnant women and the health system, which in turn leads to a lack of hospitalization planning regarding childbirth.

\section{REFERENCES}

1. Almeida CAL, Tanaka OY. Perspectivas das mulheres na avaliação do Programa de Humanização do Pré-natal e Nascimento. Rev Saude Publica. 2009;43(1):98-104. DOI:10.1590/S0034-89102009000100013

2. Almeida WS, Szwarcwald CL. Mortalidade infantil e acesso geográfico ao parto nos municípios brasileiros. Rev Saude Publica. 2012;46(1):68-76. DOI:10.1590/S0034-89102012005000003

3. Assis MMA, Jesus WLA. Acesso aos serviços de saúde: abordagens, conceitos, políticas e modelo de análise. Cienc Saude Coletiva. 2012;17(11):2865-75. DOI:10.1590/S1413-81232012001100002

4. Barbastefano PS, Girianelli VR, Vargens OMC. O acesso à assistência ao parto para parturientes adolescentes nas maternidades da rede SUS. Rev Gaucha Enferm. 2010;31(4):708-14. DOI:10.1590/S1983-14472010000400014

5. Bastos GAN, Duca GFD, Hallal PC, Santos IS. Utilização de serviços médicos no sistema público de saúde no Sul do Brasil. Rev Saude Publica. 2011;45(3):475-84. DOI:10.1590/S0034-89102011005000024

6. Carvacho IE, Mello MB, Morais SS, Silva JLP. Fatores associados ao acesso anterior à gestação a serviços de saúde por adolescentes gestantes. Rev Saude Publica. 2008;42(5):886-94. DOI:10.1590/S0034-89102008000500014

${ }^{\mathrm{d}}$ Ministério da Saúde. Portaria $\mathrm{n}^{\circ}$ 1.459, de 24 de junho de 2011. Institui no âmbito do Sistema Único de Saúde - SUS - a Rede Cegonha. Diario Oficial Uniao; 27 jun 2011
7. Cesar JA, Mendonza-Sassi RA, Gonzáles-Chica DA, Mano PS, Gourlat-Filha SM. Características sociodemográficas e de assistência à gestação e ao parto no extremo sul do Brasil. Cad Saude Publica. 2011;27(5):985-94. DOI:10.1590/S0102-311X2011000500016

8. Domingues RMSM, Hartz ZMA, Dias MAB, Leal MC. Avaliação da adequação da assistência pré-natal na rede SUS do Município do Rio de Janeiro, Brasil. Cad Saude Publica. 2012;28(3):425-37. DOI:10.1590/S0102-311X2012000300003 
9. Enkin MW, Keirse M, Neilson JP, Crowther CA, Duley L, Hodnett ED et al. Guia para atenção efetiva na gravidez e no parto. $3^{\text {a }}$ ed. Rio de Janeiro (RJ): Guanabara Koogan; 2005.

10. Fernandes LCL, Bertoldi AD, Barros AJD. Utilização dos serviços de saúde pela população coberta pela Estratégia de Saúde da Família. Rev Saude Publica. 2009;43(4):595-603. DOI:10.1590/S0034-89102009005000040

11. Hosmer DW Jr, Lemeshow S. Applied logistic regression. $2^{\text {nd }}$ ed. New York: John Wiley \& Sons; 2004.

12. Kassar SB, Lima MC, Albuquerque MFM, Barbiere MA, Gurgel RQ. Comparações das condições socioeconômicas e reprodutivas entre mães adolescentes e adultas jovens em três maternidades públicas de Maceió, Brasil. Rev Bras Saude Matern Infant. 2006;6(4):397-403. DOI:10.1590/S1519-38292006000400006

13. Leal MC, Gama SG, Campos MR, Cavalini LT, Garbayo LS, Brasil CL et al. Fatores associados à morbi-mortalidade perinatal em uma amostra de maternidades públicas e privadas do Município do Rio de Janeiro, 1999-2001. Cad Saude Publica. 2004;20(Suppl 1):S20-33. DOI:10.1590/S0102-311X2004000700003

14. Leal MC, Silva AAM, Dias MAB, Gama SGN, Rattner D, Moreira ME et al. Birth in Brazil: national survey into labour and birth. Reprod Health. 2012;9:15. DOI:10.1186/1742-4755-9-15.

15. Menezes DCS, Leite IC, Schramm JMA, Leal MC. Avaliação da peregrinação anteparto numa amostra de puérperas no Município do Rio de Janeiro, Brasil, 1999/2001. Cad Saude Publica. 2006;22(3):553-9. DOI:10.1590/S0102-311X2006000300010.

16. Ministério da Saúde, Centro Brasileiro de Análise e Planejamento. Pesquisa nacional de demografia e saúde da criança e da mulher - PNDS 2006; dimensões do processo reprodutiva e da saúde da criança. Brasília (DF): 2009. (Série G. Estatística e informação em saúde).

17. Paris V, Devaux M, Wei L. Health systems institutional characteristics: a survey of 29 OECD countries. OECD Health Working Papers. 2010;(50). DOl:10.1787/5kmfxfq9qbnr-em

18. Santos L, Andrade LOM. Acesso às ações e aos serviços de saúde: uma visão polissêmica. Cienc Saude Coletiva. 2012;17(11):2876-8. DOI:10.1590/S1413-81232012001100003

19. Souza JP, Parpinelli MA, Amaral E, Cecatti JG. Assistência obstétrica e complicações graves da gestação na América Latina e Caribe: análise das informações obtidas a partir de inquéritos demográficos de saúde. Rev Panam Salud Publica. 2007;21(6):396-401. DOI:10.1590/S1020-49892007000500008

20. Usta IM, Zoorob D, Abu-Musa A, Naasan G, Nassar AH. Obstetric outcome of teenage pregnancies compared with adult pregnancies. Acta Obstet Gynecol Scand. 2008;87(2):178-83. DOI:10.1080/00016340701803282

21. Victora CG, Matijasevich A, Silveira MF, Santos IS, Barros AJD, Barros FC. Socio-economic and ethnic group inequities in antenatal care quality in the public and private sector in Brazil. Health Policy Plan. 2010;25(4):253-61. DOI:10.1093/heapol/czp065

22. Victora CG, Aquino EML, Leal MC, Monteiro CA, Barros FC, Szwarcwald CL. Maternal and child health in Brazil: progress and challenges. Lancet. 2011;377(9780):1863-76. DOI:10.1016/S0140-6736(11)60138-4

23. Viellas EF, Gama SGN, Theme Filha MM, Leal MC. Gravidez recorrente na adolescência e os desfechos negativos no recém-nascido: um estudo no município do Rio de Janeiro. Rev Bras Epidemiol. 2012;15(3):443-54. DOI:10.1590/S1415-790X2012000300001

Funding: Fundação para Desenvolvimento Científico e Tecnológico em Saúde of the Escola Nacional de Saúde Pública/Fundação Oswaldo Cruz (ENSP/FIOCRUZ) and the Conselho Nacional de Desenvolvimento Científico e Tecnológico (CNPq - Opinion 057/2009).

Authors' Contribution: Study design and planning: EZLF and KROG. Data analysis and interpretation: EZLF and KROG. Manuscript drafting: EZLF, KROG and SGNG. Critical review: EZLF, KROG and SGNG. All authors approved the final version of the manuscript.

Conflict of interest: The authors declare no conflict of interest. 